ZNZ [The relevance of the study of the problem of implementing computerbased support for students of secondary schools' inclusive education]. Pedahohika zdorov"ya: zb. nauk. prats' VI Vseukrayins'koyi naukovopraktychnoyi konferentsiyi KhNPU im. H.S. Skovorody, 679-681 [in Ukrainian].

Ovcharuk, O. V., Hrytsenchuk, O. O., Ivanyuk, I. V., Kravchyna, O. Ye., Malyts'ka, I. D. \& Soroko, N. V. (2018). Yevropeys'kyy dosvid rozvytku tsyfrovoyi kompetentnosti vchytelya $v$ konteksti suchasnykh osvitnikh reform [European experience of teacher's digital competence development in the context of modern educational reforms]. Informatsiyni tekhnolohiyi $i$ zasoby navchannya, 3 (65), 317-336 [in Ukrainian].

Hafizullina, I. N. (2007). Formirovanie professional'noj kompetentnosti pedagoga obshheobrazovatel'noj shkoly v rabote s det'mi s osobymi obrazovatel'nymi potrebnostjami [Forming a school teacher's professional competence of working with children who have special educational needs]. Vestnik Kostromskogo gosudarstvennogo universiteta im. N.A.Nekrasova. Serija: Pedagogika. Psihologija. Social'naja rabota. Juvenologija. Sociokinetika, 13 (1), 83-88 [in Russian].

Hitrjuk, V. V. (2014). Koncepcija formirovanija inkljuzivnoj gotovnosti pedagogov [Conception of teachers' inclusive readiness' forming]. Vestnik ChGPU im. I.Ja. Jakovleva. Pedagogicheskie nauki, 1 (81), 163-169 [in Russian].

Chaykovs'kyy, M. (2012). Inklyuzyvna kompetentnist' yak skladova profesiynoyi kompetentnosti sub"yektiv osvitn'oho protsesu [Inclusive competence as a part of professional competence of educational process' subjects]. Pedahohika i psykholohiya prof. osvity, 2, 15-21 [in Ukrainian].

УдК 373.2.064.1

DOI: https://doi.org/10.35387/od.2(18).2020.75-86

Квасецька Ярина Андріївна - кандидат педагогічних наук, асистент кафедри педагогіки та психології дошкільної освіти Чернівецького національного університету імені Юрія Федьковича

ORCID iD: http://orcid.org/0000-0003-4270-878X

E-mail:y.kvasetska@chnu.edu.ua

\title{
ПЕДАГОГІЗАЦІЯ БАТЬКІВ В УМОВАХ ЗАКЛАДІВ ДОШКІЛЬНОЇ ОСВІТИ
}

Анотація. Оәлядову статтю присвячено аналізу проблеми педагогізації батьків вихованців закладів дошкільної освіти в умовах транссрормації інфрормаційно-технологічного суспільства і зростання ролі освіти як цивілізаційного ресурсу. Здійснено огляд сучасних досліджень $i$ публікацій, ретроспективний аналіз питання взаємодії дошкільного закладу і сім'ї на різних етапах суспільного розвитку. Розкрито й уточнено сутність поняття «педагогізація», відзначено особливості його трактування в сфрері педагогіки і психології, обгрунтовано доцільність 
вживання поняття "педагогізація співпраці з батьками» в контексті навчально-виховного (освітнього) процесу в дошкільних закладах. На підставі узагальнення досвіду роботи педагогічного колективу закладу дошкільної освіти № 33 Центр розвитку дитини "Оселя талановитих» (м. Чернівці) виокремлено 3 етапи співпраці дошкільного закладу 3 батьками, які включають вивчення сімїі, педагогічну співпрацю з батьками, залучення батьків до участі в житті дошкільного закладу.

Акцентовано увагу на важливості вивчення соціальних умов кожної сімї, знань про освіту батьків і членів сімей, національно-культурні традииії, практиковані форми i методи сімейного виховання дітей. Проаналізовано форми педагогічної співпраці з батьками, які можна поділити на традиційні та інноваційні. До традиційних фрорм належать конферениії (збори), «круглі столи», семінари-практикуми, дискусії, бесіди тощо. Інноваційні форми представляють психолого-педагогічні тренінги, рольові ігри, батьківські тренінги і ринги тощо. Наголошено, що найкращого результату допомагає досягати комплексне поєднання традиційних та інноваційних фрорм. Зроблено висновок, що педагогізація співпраці дошкільного закладу і батьків - це багатовекторний процес, що грунтується на знаннях з питань загальної $і$ соціальної педагогіки, психології, теорії та практиці діалогічної взаємодії між педагогами, дітьми і батьками.

Ключові слова: педагогізація, освіта дорослих, дошкільний заклад, педагогічна співпраця з батьками, діти, освітній процес, «Оселя талановитих».

Kvasetska Yaryna - Candidate of Pedagocial Sciences (PhD), Assistant of the Department of Pedagogics and Psychology of Pre-School Education of the Yuriy Fedkovych Chernivtsi National University

ORCID iD: http://orcid.org/0000-0003-4270-878X

E-mail:y.kvasetska@chnu.edu.ua

\section{PEDAGOGIZATION OF PARENTS IN CONDITIONS OF PRE-SCHOOL EDUCATION INSTITUTIONS}

Abstract. The review article focuses on analyzing the problem of pedagogization of relationships between pre-school educational institutions and children's parents in the conditions of transformation of informationaltechnological society and rising role of education as a civilizational resource. Modern research and publications have been reviewed, the problem of cooperation of a pre-school educational institution and a family on different stages of social development has been analyzed. The notion of pedagogization has been defined and clarified, peculiarities of its interpretation in the areas of pedagogy and psychology have been recognized, relevance of using the notion of pedagogization of cooperation with parents in the context of an educational 
process at pre-school educational institutions have been presented. On the grounds of work experience of the pedagogical personal of the pre-school educational institution № 33 "Center for Child Development «Home for the Talented» (Chernivtsi) three stages of cooperation of an educational institution with parents have been singled out, that include getting to know a family, pedagogical cooperation with parents, involvement of parents into activities of an educational institution.

Special attention is paid to importance of learning about social circumstances of each family, education of parents and other family members, national and cultural traditions, practiced forms and methods of family children upbringing. Forms of pedagogical cooperation with parents have been analyzed, which can be divided into traditional and innovational ones. Traditional ones include conferences (meetings), "round tables». Seminars and workshops, discussions, talks. Innovational ones are psychological-pedagogical trainings, roleplay, parents' trainings and rings. It has been stated that the best result can be achieved complex combination of traditional and innovational forms. Conclusion has been made that pedagogization of cooperation of a pre-school educational institution and parents is a multivector process which is based on knowledge of general and social pedagogy, psychology, theory and practice of dialog interaction between pedagogues, children and parents.

Key words: pedagogization, adult education, pre-school educational institution, pedagogical cooperation with parents, children, educational process, «Home for the Talented».

Постановка проблеми, їі актуальність. Ідея взаємозв'язку суспільного й сімейного виховання пронизує всю систему теорії і практики дошкільної педагогіки. Ще Фрідріх Вільгельм Фребель, засновник «дитячого садка» і оригінальної системи суспільного дошкільного виховання, обґрунтував необхідність поєднання сімейного і дошкільного виховання, наголошуючи на важливості дошкільного закладу як освітнього майданчика для підвищення педагогічних знань батьків (Квасецька, 2017, с. 101).

На різних етапах суспільного розвитку проблема взаємодії дошкільного закладу і сім'ї постає у нових якостях і вимірах, що знаходить своє відображення у зміні термінології, у трактуваннях усталених виразів, понять і процесів. У радянський період суспільне дошкільне виховання, як складова частина загальної системи народної освіти, було покликане «разом із сім'єю закласти основи особистості дитини, здійснювати комуністичне виховання дітей дошкільного віку і підготовку їх до школи» (Таранова, 1986, с. 3). У незалежній Україні підходи до цієї проблеми суттєво змінені. Відбулася демократизація, гуманізація і декомунізація освітнього процесу. Як зазначається в законі України «Про дошкільну освіту» (2001), система дошкільної освіти «забезпечує розвиток, виховання і навчання дитини, ґрунтується на поєднанні сімейного та суспільного виховання, досягненнях вітчизняної науки, надбаннях світового педагогічного досвіду, сприяє 
формуванню цінностей демократичного правового суспільства в Україні». Таким чином, сім'я, разом з дітьми і колективом дошкільного закладу, стає одним із трьох головних суб'єктів освітнього процесу. Сім'я зобов'язана сприяти здобуттю дитиною освіти у дошкільних та інших навчальних закладах або забезпечити дошкільну освіту в сім'ї відповідно до вимог Базового компонента дошкільної освіти (Богуш, 2012). У той же час відвідування дитиною закладу дошкільної освіти не звільняє сім'ю від обов'язку виховувати, розвивати й навчати її в родинному колі.

Аналіз останніх досліджень і публікацій. Питання взаємодії закладу дошкільної освіти та сім'ї перебуває в полі зору сучасних дослідників. Роль дошкільного закладу та сім'ї у формуванні особистості у дошкільному дитинстві досліджували А. Богуш, Л. Божович, Л. Виготський, Н. Гавриш, О. Кононко; педагогізацію батьків як актуальну проблему освіти дорослих аналізували Л. Загик, Т. Котирло, Л. Островська, Д. Щербина; форми і методи розвитку психолого-педагогічних, соціальних компетентностей батьків (опікунів) та інших членів родини в системі неформальної освіти дорослих розглядали О. Аніщенко, М. Араджионі, А. Гусєв, В. Потапова; питання змісту і методів педагогічної взаємодії педагогів дошкільного закладу з батьками відображені у працях О. Долинної, С. Івах, М. Савченко, Д. Струннікової; на важливості забезпечення умов для спільної роботи сім'ї та педагогічного колективу в освітніх закладах наголошували Т. Алексєєнко, В. Безлюдна, В. Постовий.

Метою статті $\epsilon$ аналіз проблеми педагогізації співпраці батьків і педагогів в умовах закладів дошкільної освіти з урахуванням новітніх наукових досліджень і практики реалізації теоретичних напрацювань у закладі дошкільної освіти № 33 Центр розвитку дитини «Оселя талановитих» (м. Чернівці), обґрунтування ефективних форм і методів роботи.

Виклад основного матеріалу дослідження. Початок відвідування дитиною закладу дошкільної освіти- це своєрідний вихід її із зони сімейного комфорту та входження в нове соціокультурне середовище. Найгостріша проблема батьків у цей період, щоб їхню дитину зрозуміли, тепло і щиро прийняли незалежно від того, наскільки тішить вона дорослих - батьків і дошкільних педагогів.

Усвідомлення важливості уваги «до почуттів, думок і готовності їх почути; готовності до підтримки вихованця, ... віра в його сили і можливості» (Бех, 2003, с. 63), розуміння того, що саме з раннього дитинства успадковується дитиною сприйняття себе і світу, зумовлює доцільність активно працювати над собою вихователів-педагогів, узгоджувати колективні, групові та індивідуальні фрорми і методи роботи, враховувати педагогічний вплив різних видів діяльності. Водночас для працівників дошкільного закладу важлива довіра батьків.

Одним з найбільш важливих чинників успішної адаптації та розвитку дітей в умовах закладу дошкільної освіти $є$ сім'я та їх найближче оточення. Це зазвичай те перше й дуже специфічне соціальне середовище, в якому 
дитина розвивається, пізнає світ. Культура сімейних стосунків, родинні традиції зберігаються й передаються з покоління в покоління.

У контексті нашого дослідження особливо важливого значення набуває й рівень педагогічних знань і розуміння батьками та рідними дитячої психології, форм і методів сімейного виховання, усвідомлення готовності стати суб'єктом освітнього (навчально-виховного) процесу під час перебування їх дітей в дошкільному закладі. Особливої актуальності набуває розвиток педагогічної культури батьків як категорії дорослих, що навчаються, підвищення педагогічної і психологічної компетентності, набуття навичок 3 педагогічної емпатії та рефлексії, тобто здатності адекватно реагувати на вчинки і почуття дітей, критично оцінювати власну виховну діяльність. Отже, йдеться про педагогізацію батьків і членів родин.

Термін педагогізація претендує на універсальність і його можна розглядати не тільки в контексті педагогіки, але й філософії, соціології та психології. На думку видатного педагога С. Шацького, «педагогізація середовища» означала розробку теорії та методики взаємодії школи 3 іншими освітніми закладами та сім'ями, вивчення й використання виховних можливостей соціального середовища в цілому; усвідомлене насичення, збагачення соціального середовища виховним потенціалом. Натомість психологи трактують поняття педагогізація як педагогічну активно-дієву спрямованість свідомості, як складний процес послідовних дій, спрямованих на пробудження у людини інтересу до себе як до вихователя, розвиток людиною своїх педагогічних знань, умінь і навичок, участь у розв'язанні педагогічних проблем на основі існуючих педагогічних знань та власного досвіду (Савченко, 2012).

Таким чином, поняття педагогізація співпраці з батьками можна трактувати, як безперервний освітній процес, організований педагогами дошкільного чи загальноосвітнього закладу з метою розвитку педагогічних компетентностей батьків, вирішення психолого-педагогічних і соціокультурних проблем виховання дитини в колі сім'ї і в межах закладу освіти. Методологічною основою педагогічної освіти батьків $€$ народний педагогічний досвід, досягнення вітчизняної та зарубіжної наукової педагогіки з питань сімейного виховання.

Термін педагогізація батьків можна розглядати як близький за значенням до педагогізація співпраці з батьками, але не тотожним. Оскільки він звужує значення батьків як суб'єктів освітнього процесу в дошкільному закладі й акцентує увагу на їхній суб'єктності. Процес педагогізації співпраці з батьками можна поділити на 3 етапи: вивчення сім'ї, педагогічна співпраця з батьками; залучення батьків до участі в житті дошкільного закладу.

Налагодження партнерських стосунків із сім'ями дошкільнят, які вступають в заклад дошкільної освіти № 33 «Оселя талановитих» (м. Чернівці), починаються зі збору необхідної інформацію про дитину, їі родину. Це відбувається шляхом анкетування, бесід 3 батьками, 
спостереження за дітьми, педагогічної діагностики. У цьому контексті важливими є: «Анкета для батьків, діти яких вперше поступають в заклад дошкільної освіти» та «Індивідуальна картка психологічного супроводу», які допомагають розкрити особливості сімейних відносин, індивідуальні особливості дітей. Увага звертається на соціальні аспекти - житловопобутові умови, склад, вік і зайнятість членів сім'ї, на світоглядний і культурно-освітній рівень, характер сімейних і національно-культурних традицій, культуру домашнього побуту. Педагоги закладу намагаються виявити форми і методи сімейного виховання дітей - види практикованих занять і розваг, засоби заохочень і покарань, улюблені ігри та іграшки, приклад батьків і використання авторитету старших членів родини. Важливими питаннями є оцінка батьками рівня розвитку дитини та їхні очікування від відвідування закладу дошкільної освіти.

Зібрана інформація свідчить, що 93 \% дітей, які вступають в заклад дошкільної освіти «Оселя талановитих», виховуються у повних сім'ях. Більшість батьків (73\%) мають вищу освіту, майже половина мам не працюють. Приблизно $40 \%$ дітей привозять в дошкільний заклад громадським транспортом або особистим авто, витрачаючи на дорогу 3040 хв.

Результати анкетування свідчать, по-перше, про дуже високий загальноосвітній рівень батьків та розуміння ними важливості як сімейного виховання, так і розвитку їхніх дітей в суспільних освітніх закладах; по-друге, про усвідомлений вибір батьками дошкільного закладу, який може забезпечити належний рівень розвитку, виховання і навчання дітей.

Всебічний і гармонійний розвиток дітей $є$ пріоритеттом діяльності закладу дошкільної освіти «Оселя талановитих» ще 3 дев'яностих років минулого століття. Заклад і донині підтримує свою добру репутацію. Серед сімей, які вперше привели своїх дітей у 2020 р., лише $7 \%$ обрали заклад у зв'язку з його близьким місцерозташуванням. Ще 20 \% враховували зручне місцерозташування і свої безпосередні враження від контактів 3 працівниками закладу. Натомість, для абсолютної більшості батьків першочергове значення мали добрі відгуки сімей, діти яких відвідували заклад. Навіть дорога у 30-40 хв. не вважається серйозною перешкодою для відвідування.

Опитування батьків виявили чимало проблемних питань виховання дітей у сім'ях. Якщо практично всі діти спільно з батьками дивляться фрільми, шоу, спортивні програми, то близько 70 \% дітей переглядають телепередачі без контролю батьків - аби «дитина не вередувала», щоб «не бігала по квартирі, бо мала площа». Лише 55 \% батьків грають 3 малятами, а ще менше (44 \%) сімей назвали цікавими перегляд та читання дитячих книг.

Батьки мало уваги приділяють таким заняттям, як: малювання, ліплення, відвідування театру, дуже рідко заохочують дітей до посильної домашньої праці (лише 23 \% батьків і родичів доручають дітям складати свої іграшки). Причинами такої ситуації батьки часто називають зайнятість, брак 
життєвого досвіду, наявність матеріальних проблем тощо. Однак здебільшого вони виокремлюють недостатню обізнаність щодо педагогічних аспектів виховання, констатують спорадичне застосування, а то й ігнорування педагогічних засад у родинному вихованні. Низький рівень педагогічної компетентності і, відповідно, сумніви у спроможності сучасної сім'ї забезпечити успішне виховання своїх дітей виявило опитування, проведене в закладі дошкільної освіти № 398 м. Києва. Так, на запитання, чи здатна сім'я повноцінно виконувати свої виховні функції, лише 22 \% з 273 опитаних осіб відповіли, що повністю здатна. Найбільша частина респондентів - $41 \%$ - вважала, що сім'я скоріше здатна, ніж не здатна повноцінно виконувати свої виховні функції. Натомість $23 \%$ опитаних сумнівалися в здатності сім'ї забезпечити належне виховання - «скоріше не здатна, ніж здатна», а 3 \% респондентів вважали, що «повністю не здатна». Значна частина опитаних $11 \%$ (30 осіб) - вагалися з вибором відповіді, зазначаючи, що на це питання «важко відповісти» (Котирло, 2019, с. 95).

Отримані дані опитування батьків у закладах дошкільної освіти Чернівців і Києва однозначно свідчать про актуальність питання педагогізації співпраці з батьками в період відвідування дітьми дошкільного закладу. Однією з відповідей педагогічного колективу закладу дошкільної освіти «Оселя талановитих» на подібні виклики стала розробка адаптаційнорозвивальної технології соціалізації дитини в умовах дошкільного навчального закладу, в якій особлива увага приділена питанню педагогізації співпраці педагогічного колективу з батьками.

Зазначимо, що співпраця з батьками будується на партнерських засадах із дотриманням таких правил: повага до батьків та індивідуальний підхід до співпраці з родинами щодо сімейного виховання; заохочення батьків до різних форм роботи з дітьми та педагогами з метою формування вмінь правильного оцінювання успіхів дитини, прогнозування перспектив її розвитку; доброзичливість, терпимість до іншої думки, оптимістичність (Я. Квасецька, М. Квасецька, Ю. Апостолюк, \& М. Омахіль, 2017, с. 53).

У процесі педагогізації батьків використовуються як традиційні, так і інноваційні форми роботи (рис. 1). До традиційних форм належать «круглі столи», семінари-практикуми, дискусії, бесіди. Нині часто можна почути твердження, що традиційні форми роботи не дають бажаного ефекту. Таке твердження не зовсім справедливе. Наприклад, така форма індивідуальної роботи як бесіда, допомагає налагодити довірливі взаємини між педагогом і сім'єю, краще зрозуміти характер, вчинки і переживання дітей. За умови ретельної підготовки і грунтовного аналізу обговорюваних питань, можна досягти реального результату. 


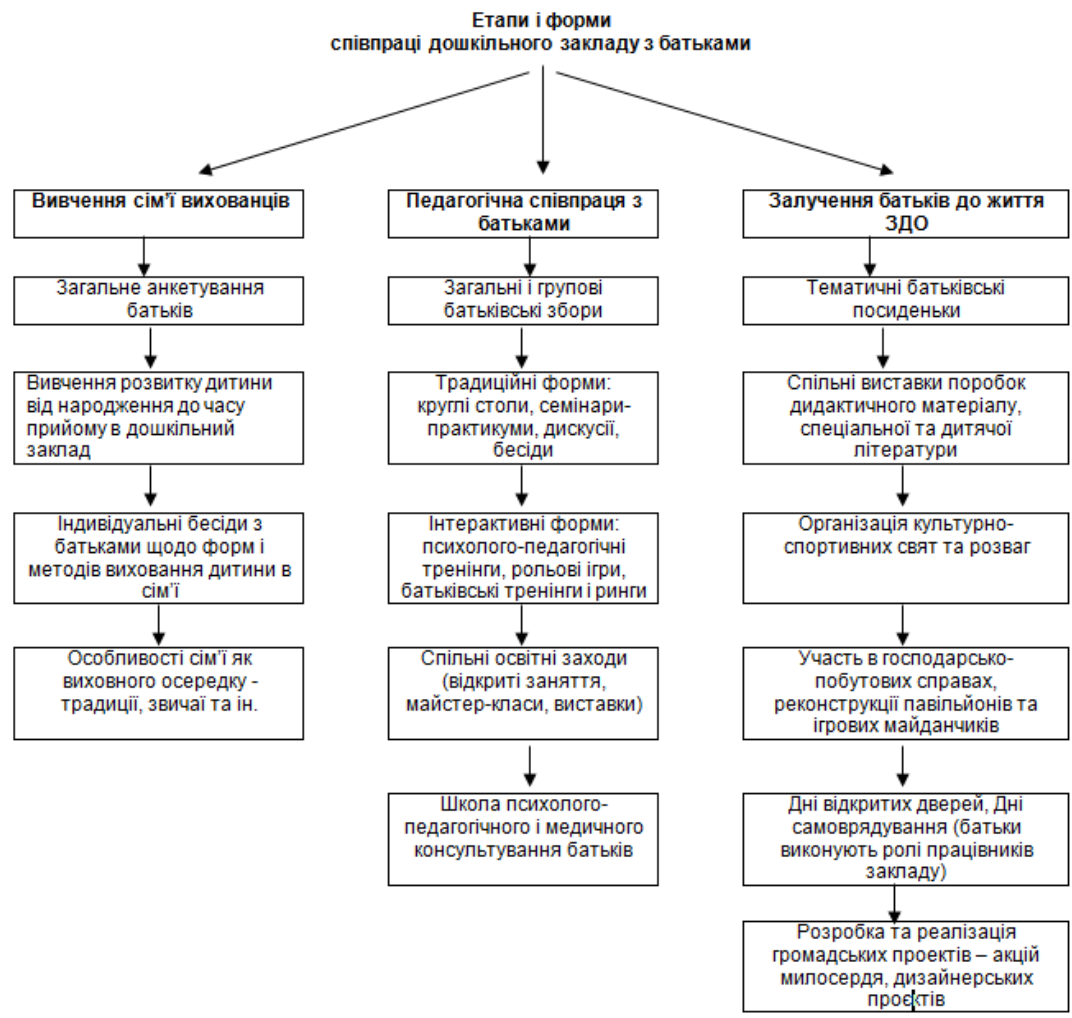

Рис. 1. Етапи, форми і методи співпраці з батьками вихованців закладів дошкільної освіти

На думку науковців і педагогів дошкільної освіти, позитивний ефект дають такі активні фооми колективної роботи з батьками, як семінарипрактикуми, тематичні консультації. Семінари-практикуми, зазвичай, присвячено одній виховній проблемі. Ефективність їх проведення забезпечується вдалим вибором виховної проблеми, врахуванням освітнього рівня та зацікавленості батьків, вмінням педагогів узагальнити обговорення у фрормі практичних рекомендацій. Як слушно наголошують автори-розробники освітньої програми «Батьківські збори по-новому: актуально, інтерактивно, корисно», розвиток психолого-педагогічних, соціальних і громадських компетентностей батьків необхідно здійснювати «на основі врахування їхніх культурно-освітніх потреб, спрямованості на подальше використання в реальних життєвих ситуаціях набутих у процесі 
навчання знань, умінь і навичок». (О. Аніщенко \& В. Потапова, 2019, с. 9).

3 огляду на такі вимоги важливою складовою педагогічної співпраці з батьками $є$ інтерактивні форми роботи - психолого-педагогічні тренінги, рольові ігри, батьківські тренінги, ринги тощо. Вони стали простором для виявлення творчої ініціативи батьків, в ігровій формі максимально наближують учасників до реальних обставин, сприяють прийняттю педагогічно правильних рішень й обміну батьківським педагогічним досвідом. Якщо під час традиційних заходів модератором відносин між колективом і сім'єю виступають працівники дошкільного закладу, то в психологопедагогічних тренінгах і рольових іграх провідну роль відіграють батьки. Таким чином забезпечується зворотній зв'язок у процесі педагогізації відносин між колективом закладу дошкільної освіти і батьками, коли педагогізуються і батьки, і педагоги.

Міцним підґрунтям успішної взаємодії закладу дошкільної освіти з батьками $є$ участь батьків в освітньому процесі, відкритість закладу для батьків, дітей та громадськості. У цьому контексті важливим засобом підвищення педагогічної культури батьків $€$ День самоврядування, який проводиться у закладі дошкільної освіти «Оселя талановитих» на початку кожного нового навчального року. За місяць до його проведення видається спеціальний наказ, в якому зазначаються відповідальні особи за організацію Дня самоврядування, основні підготовчі заходи. На основі опитування батьків проводиться відбір з числа батьків - дублерів вихователів, практичного психолога, директора та інших спеціалістів. Значна увага приділяється ознайомленню дублерів із посадовими інструкціями та інструкціями з охорони праці, проведенню інструктажів, ознайомлення дублерів із нормативно-правовою базою дошкільної освіти, зокрема 3 Базовим компонентом дошкільної освіти, освітньою програмою.

Підготовкою дублерів передбачено їх стажування у спеціалістів за 13 дні до заходу, складання, обговорення та затвердження плану роботи, зокрема заняття та його методичного та дидактичного забезпечення.

Переважна більшість батьків дуже відповідально ставляться до ролі вихователя-дублера, директора-дублера та інших членів педагогічного колективу. Вони стажуються у провідних спеціалістів, спостерігають за роботою вихователів з дітьми під час занять, прогулянок, ігрової діяльності, харчування тощо. Уважно переглядають відео-фрагменти різних видів діяльності та участь фахівців у них.

Батькам, які виконують роль вихователів, надається унікальна можливість поспостерігати за своєю дитиною під час іï взаємодії 3 однолітками не в домашніх умовах, а на різних майданчиках (група, зал, клас) та з різними дітьми. Як правило, після такого заходу у батьків виникає багато запитань до вихователів, практичного психолога, директора щодо подальшого виховання своєї дитини, використання тих чи інших засобів педагогічного впливу. Батьки досить часто визнають, що їм бракує знань і вмінь для ефективної взаємодії з власними дітьми, а дублери-вихователі 
переддошкільних груп переконуються у важливості власного повсякденного прикладу, відвертості у спілкуванні.

Висновки і перспективи подальших досліджень. Результати здійсненого дослідження дають підстави для висновку про те, що в умовах трансформації сучасного інформаційно-технологічного суспільства зростає роль партнерства закладу дошкільної освіти та батьків як головних організаторів та учасників освітнього процесу в дошкільних закладах. Важливими умовами результативної взаємодії $\epsilon$ педагогізація батьків, що передбачає налагодження тісних і довірливих контактів, узгодження педагогічних вимог і виховних впливів, розвиток психолого-педагогічної культури батьків і професійної компетентності педагогів, комплексного використання традиційних та інноваційних форм співпраці, підвищення відповідальності кожної зі сторін за створення розвивального предметнопросторового середовища в дошкільному закладі та в домашніх умовах.

Педагогізація батьків в умовах закладу дошкільної освіти - це багатовекторний процес, що ґрунтуються на знаннях із загальної, соціальної та дошкільної педагогіки, психології, теорії та практики діалогічної взаємодії між педагогами, дітьми і батьками. Ефективність цього процесу значною мірою залежить від розроблення та впровадження сучасних програм і технологій неформальної освіти педагогів, батьків та інших членів родини.

Перспективним напрямом подальших досліджень $€$ науковометодичне забезпечення педагогізації відносин між колективами закладів дошкільної освіти і батьками вихованців, виявлення тенденцій і позитивного досвіду в контексті вітчизняної та зарубіжної науки та практики.

\section{Список використаних джерел}

Аніщенко, О. В., Араджионі, М.А., Гусєв, А.І. \& Потапова, В.І. (Ред.). (2019). Культура добросусідства. Батьківські збори по-новому: актуально, інтерактивно, корисно.

URL: https://lib.iitta.gov.ua/719391/.

Бех І. Д. (2003) Виховання особистості: У 2 кн. Кн.1: Особистісноорієнтований підхід: теоретико-технологічні засади. К.: Либідь, 280.

Богуш, А. М., Бєлєнька, Г. В., Богініч, О. Л., Гавриш, Н. В., Долинна, О. П., Ільченко, Т. С. ... \& Якименко, Л. Ю. (2012) Базовий компонент дошкільної освіти. К.: Видавництво, 26.

Закон України «Про дошкільну освіту». № 2628-III (2001). URL: https://zakon.rada.gov.ua/laws/show/2628-14\#Text

Івах, C. М. (2013) Особливості педагогізації батьків дітей дошкільного віку. Педагогіка вищої та середньої школи, Кривий Ріг: КПІ ДВНЗ «КНУ», 37, 285-289.

Квасецька, Я. А., Квасецька, М. В., Апостолюк, Ю. В. \& Омахіль, М. Г. (2017) Адаптаційно-розвивальна технологія соціалізації дитини в умовах дошкільного навчального закладу (з досвіду роботи ДНЗ №33 ЦРД «Оселя талановитих», м. Чернівці). Чернівці: Зелена Буковина, 
140.

Квасецька, Я.А. (2017) Профресійна підготовка вихователів дошкілля на західноукраїнських землях: історичний аспект. Чернівці: Зелена Буковина, 352.

Котирло, Т.В. Педагогізація батьків і членів родин як актуалітет освіти дорослих. Освіта дорослих: теорія, досвід, перспективи. К., 91-99.

Новик, І. М. \& Ткаченко, К. О. (2017). Педагогічне просвітництво батьків. Молодий вчений, 12 (52), 417-420

Паскевська Ю.А. \& Щербина, Д.В. (2019). Педагогічні засади організації просвіти батьків у загальноосвітніх, позашкільних закладах. К.: ІПООД імені Івана Зязюна НАПН України, 105.

Постовий, В.Г. (1994). Сучасна сім'я та ї̈ педагогіка. К.: Освіта. 284.

Савченко, М.С. (2012). Особливості спільної діяльності сім'ї та дошкільного навчального закладу з питань ґендерного виховання. Матеріали дев'ятої Міжнар. наук.-практ. Інтернет-конф. "Соціум. Наука. Культура». Київ. 32-36. URL: http://surl.li/inqq

Струннікова, Д.І. (2001) Виховання в сімї як одна з умов соціалізації особистості дитини. Збірник наукових праць Інституту психології ім. Г.С.Костюка АПН України «Проблеми загальної та педагогічної психології», 3, 4, 178-183.

Таранова, Є.А. (Ред.). (1986). Програма виховання та навчання в дитячому садку. К.: Радянська школа, 208.

\section{References (translated and transliterated)}

Anishchenko, O. V., Aradzhyoni, M.A., Husiev, A.I. \& Potapova V.I. (Eds.). (2019). The culture of good neighborliness. Parent meeting in a new way: relevant, interactive, useful. URL: https://lib.iitta.gov.ua/719391/ [in Ukrainian].

Bekh, I.D. (2003) Education of personality: In 2 books. Book 1: Personality-oriented approach: theoretical and technological principles. Kyiv: Lybid [in Ukrainian].

Bohush, A.M., Bielienka, H.V., Bohinich, O.L., Havrysh, N.V., Dolynna, O.P., Ilchenko, T.S. \& Yakymenko, L.Yu. (2012) The basic component of preschool education. Kyiv: Vydavnytstvo [in Ukrainian].

Law of Ukraine "On Preschool Education». № 2628-III (2001). URL: https://zakon.rada.gov.ua/laws/show/2628-14\#Text [in Ukrainian].

Ivakh, S.M. (2013) Features of pedagogization of parents of preschool children. Pedahohika vyshchoi ta serednoi shkoly. Kryvyi Rih: KPI DVNZ «KNU», 37 [in Ukrainian].

Kvasetska, Ya. A., Kvasetska, M. V., Apostoliuk, Yu. V. \& Omakhil, M.H. (2017) Adaptive-developmental technology of socialization of the child in the conditions of preschool educational institution (from experience of work of preschool institution №33 Center of development of the child «Home of the talented», Chernivtsi. Chernivtsi: Zelena Bukovyna. [in Ukrainian].

Kvasetska, Ya. A. (2017) Professional training of preschool educators in the western Ukrainian lands: historical aspect. Chernivtsi: Zelena Bukovyna. [in Ukrainian]. 
Kotyrlo, T.V. Pedagogization of parents and family members as an actuality of adult education. Osvita doroslykh: teoriia, dosvid, perspektyvy. Kyiv [in Ukrainian].

Novyk, I. M. \& Tkachenko, K. O. (2017). Pedagogical education of parents. Molodyj vchenyj. 12 (52). 417-420 [in Ukrainian].

Paskevska, Yu.A., Shcherbyna, D.V. (2019). Pedagogical principles of parental education in secondary and out-of-school institutions. Kyiv: IPOOD Imeni Ivana Ziaziuna NAPN Ukrainy [in Ukrainian].

Postovyi, V. H. (1994). The modern family and its pedagogy. Kyiv: Osvita. 284. [in Ukrainian].

Savchenko, M. S. (2012). Peculiarities of joint activities of a family and a preschool educational institution on gender issues. Proceedings of the ninth international scientific-practical Internet conference "Society. Science. Culture». URL: http://surl.li/inqq [in Ukrainian].

Strunnikova, D.I. (2001) Family upbringing as one of the conditions for the socialization of a child's personality. Collection of scientific works of the G.S. Kostyuk Institute of Psychology of the Academy of Pedagogical Sciences of Ukraine «Problems of general and pedagogical psychology», 3, 4. [in Ukrainian].

Taranova, Ye. A. т (Ed.) (1986). Kindergarten education and training program. Kyiv: Radianska shkola. [in Ukrainian].

УДК [378.091.212.064.3]:316.722(477)

DOI: https://doi.org/10.35387/od.2(18).2020.86-97

Кірсанова Світлана Станіславівна - асистент кафедри іноземних мов Мелітопольського державного педагогічного університету імені Богдана Хмельницького

ORCID ID: https://orcid.org/0000-0001-9427-3189

E-mail: karrissiamercado77@gmail.com

\section{ПЕДАГОГІЧНІ УМОВИ ФОРМУВАННЯ ГОТОВНОСТІ СТУДЕНТСЬКОї МОЛОДІ ДО МІЖОСОБИСТІСНОЇ ВЗАЄМОДІї У ПОЛІКУЛЬТУРНОМУ ВИМІРІ ПЕДАГОГІЧНОЇ ОСВІТИ}

Анотація. В оглядовій статті обгрунтовано педагогічні умови формування готовності міжособистісної взаємодії студентської молоді в умовах полікультурного середовища педагогічного університету як сукупність зовнішніх і внутрішніх фракторів освітнього процесу, від реалізації яких залежить рівень сформованості готовності здобувачів вищої освіти до означеного процесу. Розвиток українського полікультурного соціуму пов'язаний із етнонаціональною політикою України. Полікультурна освіта в сучасних соціокультурних умовах претендує на статус нової освітньої парадигми, яка передбачає реалізацію моделі освітнього процесу в закладі вищої освіти з урахуванням багатокультурності (етнічної, релігійної, мовної, соціальної тощо).

мета статmі полягає в обгрунтуванні педагогічних умов 